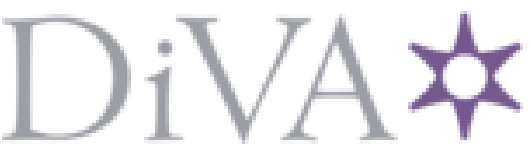

http://www.diva-portal.org

\title{
Postprint
}

This is the accepted version of a paper published in . This paper has been peer-reviewed but does not include the final publisher proof-corrections or journal pagination.

Citation for the original published paper (version of record):

Löfstrand, E., Ambrosiani, P. (2017)

The Stockholm Smolensk Archives: History, Contents and Cataloguing

Петербургский исторический журнал [Peterburgskij istoričeskij žurnal], (3): $162-173$

Access to the published version may require subscription.

N.B. When citing this work, cite the original published paper.

Permanent link to this version:

http://urn.kb.se/resolve?urn=urn:nbn:se:umu:diva-139929 


\section{THE STOCKHOLM SMOLENSK ARCHIVES: HISTORY, CONTENTS AND CATALOGUING}

\section{Abstract (English)}

This article presents the "Smolensk Archives", which consist mainly of documents from the Chancellery of Smolensk from the time of the Polish king Sigismund III's siege of the city (1609-1611), and which comprise some 1,500 sheets in all. Most of the documents are now in the Swedish National Archives in Stockholm, but a significant number are also to be found at the Institute of History of the Russian Academy of Sciences in St Petersburg. Besides documents from the Smolensk Chancellery, the archives include a number from the Polish camp outside the walls of Smolensk and a small portion of the field archives of Hetman Jan Piotr Sapieha.

The archives have a complex history. Following the fall of Smolensk in 1611, they were taken as spoils of war, ending up on the Sapieha family estate in present-day Belarus. In the mid 17th century they were seized as war booty once again - now by Swedish troops - and taken to Skokloster Castle in Sweden. There they were discovered in the 1830s by Helsinki professor Sergej Solov'ev, who in turn removed a relatively large part of the collection to St Petersburg. Portions of Solov'ev's collection of documents from Skokloster were published in 1841 in Akty istoričeskie. Around 1900, Russian historian Jurij Got'e worked on the documents from the Swedish National Archives, and in 1912 he published a text edition comprising much of the collection, Pamjatniki oborony Smolenska 1609-1611 gg.

The article includes a brief overview of the contents of the material in Stockholm, with a few examples of individual documents.

A digital catalogue of the Smolensk Archives is currently being prepared, including brief descriptions of the contents and information on external characteristics such as condition, inscriptions and watermarks. It will be supplemented with digital images of the original documents kept in Stockholm.

Keywords: Smolensk, Smutnoe vremja / Time of Troubles , siege of 1609-1611, chancellery archives, field archives of Jan Piotr Sapieha, Ksenija Godunova, spoils of war, history of archives, Swedish National Archives. 
Löfstrand \& Ambrosiani (2017): "The Stockholm Smolensk Archives..." CORRECTED PREPRINT. TO BE USED INSTEAD OF THE PUBLISHED VERSION

Abstract (Russian)

В статье представлен так называемый Смоленский архив, содержащий документы из воеводской избы времен осады Смоленска польским королем Сигизмундом III (1609-1611 гг.), в общем числе 1500 листов. Бо́льшая часть документов находится в Государственном архиве в Стокгольме, но значительное количество листов хранится и в архиве Института русской истории РАН в Санкт-Петербурге. Помимо актов из воеводской избы в Смоленском архиве также находится небольшое количество документов из польского лагеря короля Сигизмунда и около 30 листов из полевого архива гетмана Яна Петра Сапеги.

Архив смоленской воеводской избы имеет сложную историю. После падения города в 1611 г. он стал военной добычей осаждавших, и со временем он попал в имение рода Сапег в Беларуси. В середине 17-ого века он снова стал военной добычей, на этот раз шведских войск, и был перевезен в Швецию, в замок Скуклостер. Здесь в середине тридцатых годов 19-ого века его обнаружил профессор Гельсингфорсского университета С. В. Соловьев, который в свою очередь увез сравнительно большую часть собрания в Санкт-Петербург. Часть этих документов была опубликована в 1841 г. в Актах исторических. На рубеже 19-ого и 20-ого столетий историк Ю. В. Готье работал с документами Государственного архива, и в 1912 г. он издал текст 283 архивных номера из Смоленского архива в Памятниках оборонь Смоленска 1609-1611 г2.

В статье также имеется краткий обзор содержания стокгольмских документов, и представлено несколько примеров отдельных документов.

В настоящее время вырабатывается опись Смоленского архива. Результатом будет дигитальный каталог с краткими описаниями содержания каждого документа, а также со сведениями о внешних признаках, таких как, например, приписках, водяных знаках, внешнем облике. Каталог будет снабжен дигитальными копиями оригинальных документов, однако только тех, что хранятся в Швеции.

Ключевые слова: Смоленск, Смутное время, осада 1609-1611 гг., архив приказной избы, полевой архив Яна Петра Сапеги, военные добычи, архивная история, Государственный архив Швеции 


\section{Introduction}

As a result of close contacts between Sweden and its neighbours, Swedish libraries and archives hold several valuable collections of old Slavic documents. One of these collections is what is known as the Smolensk Archives, ${ }^{1}$ preserved in the Swedish National Archives in Stockholm. ${ }^{2}$ In January 2014 the project Digital Catalogue of the Stockholm Smolensk Archives was launched, with financial support from the Swedish foundation Riksbankens Jubileumsfond (RJ). The aim of the project is to create a modern digital catalogue describing the collection, which consists primarily of documents from the Chancellery of Smolensk, originating during the Polish siege of 1609-1611. With a few exceptions, the documents in the collection are written in Russian. Two Swedish Slavists, Professor Per Ambrosiani (Umeå University) and Associate Professor Elisabeth Löfstrand (Stockholm University), and the Russian historian Professor Adrian Selin (Higher School of Economics, St Petersburg) are responsible for carrying out the project. To make its results easily accessible to the international scholarly community, the language of the catalogue will be English.

\section{Archival context}

It is well known that, during the wars Sweden was involved in over the course of the 17 th century, Swedish troops brought back many cultural treasures from captured areas of Poland, Germany and other countries. These included both art objects and books, but also archival materials of various kinds. Entire libraries and archives were moved to Sweden. It was a way for the new great power to enhance its cultural standing. The scholar Sergej Dmitrievsky writes: "In removing foreign archives, the country was also pursuing practical political aims: it wanted to thoroughly penetrate the political secrets of other states - above all, of neighbours and rivals. Swedish generals and statesmen followed the example set by the Crown. They, too, carried off to Sweden numerous foreign books and archives for their private collections" (Dmitrievsky 1959: 1).

The Smolensk Archives are an example of such spoils of war. The majority of the documents originate from the archives of the Smolensk Chancellery during the Polish siege of the city from 1609 to 1611 . In addition, there are a small number of documents, in Russian, from the camp of the Polish king Sigismund III outside the city walls. There is also a third component to the archives, consisting of just over 30 sheets

\footnotetext{
${ }^{1}$ The "Smolensk Archives" is an unofficial, but often-employed, name for the collection, which will also be used in this article.

${ }^{2}$ Another Russian collection in the Swedish National Archives, from the same period, is known as the Novgorod Occupation Archives and comprises around 21,000 sheets (for details, see Löfstrand \& Nordqvist 2005, 2009).
} 
from the field archives of Hetman Jan Piotr Sapieha, from the same period but unrelated to the siege of Smolensk.

In the 19th century, the documents were kept at Skokloster Castle, north of Stockholm, together with a large collection of other older manuscripts. The Helsinki professor Sergej Vasil'evič Solov'ev arrived at Skokloster in the mid 1830s, and became aware of both the documents linked to Smolensk and Sapieha's field archives. He took a large number of sheets with him to St Petersburg, where he handed them over to the Archaeographical Commission. Today, these documents are held at the St Petersburg Institute of History of the Russian Academy of Sciences (IISPbRAN), in two collections: koll. 124 (the Solov'ev Collection) and koll. 174 (the Acts before 1613 Collection) (see further Spisok 2013). The Russian documents left behind at Skokloster, along with a large quantity of other material, were transferred in 1893 to the Swedish National Archives and included in what would be called the Skokloster Collection. In its entirety, that collection currently occupies some 80 metres of shelving. The majority of the documents are in Swedish, but the collection also includes material in Russian, Polish and other languages. Thus, as a result of the chain of events described, the documents from the three original 17th-century collections are now to be found in two archival institutions, one in Stockholm and one in St Petersburg. For a schematic overview of the history of the different document collections, see Fig. 1. 


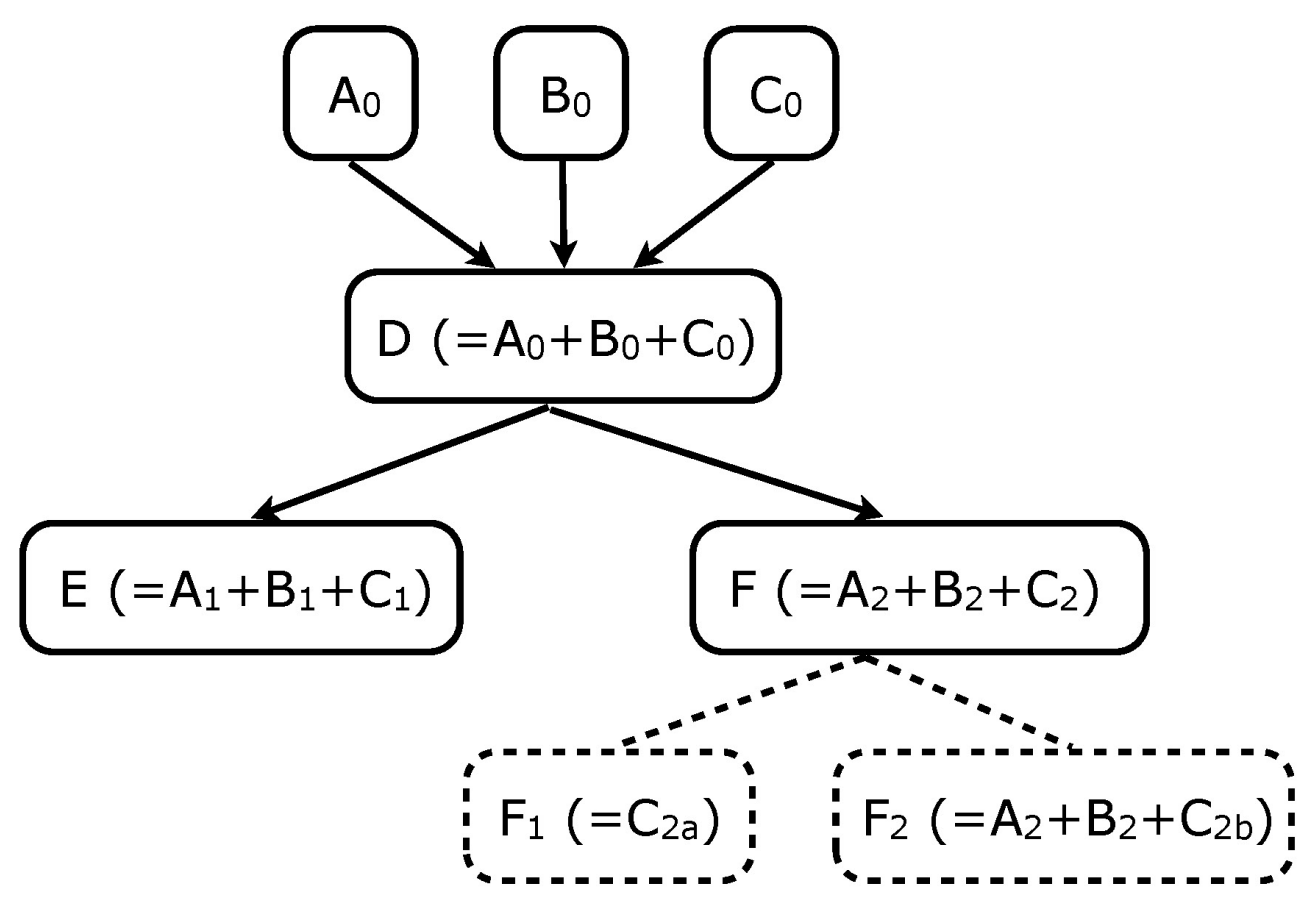

Fig. 1. Schematic overview of the origins and current locations of the collections discussed.

In the diagram, the three original collections of documents are designated $\mathbf{A}_{\mathbf{0}}$ (documents from the archives of the Chancellery of Smolensk, 1609-1611), $\mathbf{B}_{\mathbf{0}}$ (documents from Sigismund III's camp outside Smolensk, during and after the siege of the city from 1609 to 1611 ), and $\mathbf{C}_{\mathbf{0}}$ (documents from the field archives of Jan Piotr Sapieha, which consisted of material originating in connection with the fighting in the Moscow area up to and including 1611). D refers to the so-called "Brahe Collection" at Skokloster which, as we see, included documents from $\mathbf{A}_{\mathbf{0}}, \mathbf{B}_{\mathbf{0}}$ and $\mathbf{C}_{\mathbf{0}}$. $\mathbf{E}$ designates the documents taken by Solov'ev to St Petersburg, while $\mathbf{F}$ refers to the parts of the Brahe Collection which remained at Skokloster after his visit, and which were later moved to the National Archives in Stockholm. Of these, some of the documents from Jan Piotr Sapieha's field archives $\left(\mathbf{F}_{\mathbf{1}}=\mathbf{C}_{\mathbf{2}} \mathbf{a}\right)$ today constitute a separate collection, ${ }^{3}$ while the

\footnotetext{
${ }^{3}$ RA (Swedish National Archives), Skoklostersamlingen, E 8610 (no. 344, Ryska brev). Some 30 Russian documents from this collection (and more than 40 Polish ones) are reproduced in the edition by Tiumencev (2012). As we have only recently discovered, the same box also includes
} 
Löfstrand \& Ambrosiani (2017): "The Stockholm Smolensk Archives..." CORRECTED PREPRINT. TO BE USED INSTEAD OF THE PUBLISHED VERSION

"Smolensk Archives" $\left(\mathbf{F}_{2}\right)$ comprise a smaller number of documents from the field archives $\left(\mathbf{C}_{\mathbf{2 b}}\right)$, together with documents from the Chancellery archives $\left(\mathbf{A}_{\mathbf{2}}\right)$ and the Polish camp $\left(\mathbf{B}_{\mathbf{2}}\right)$.

\subsection{The "Smolensk Archives" at the National Archives in Stockholm (document collection $\boldsymbol{F}_{2}$ )}

The Smolensk Archives are held at the Swedish National Archives under the shelf mark "Skoklostersamlingen 3, Extranea, Polska och ryska handlingar, Handlingar från Smolensk, E 8610, volym 3-25" (Skokloster Collection 3, Extranea, Polish and Russian documents, Documents from Smolensk, E 8610, volumes 3-25). This shelf mark was introduced in 1979, when the collection was placed in boxes.

The history of the collection can provisionally be reconstructed as follows. When Smolensk was captured by the Polish troops in June 1611, the Chancellery archives (A) were removed by the Lithuanian Chancellor Lew Sapieha, second cousin of Hetman Jan Piotr Sapieha. Subsequently they were mixed with documents in Russian that had been among the archives of the Polish camp outside the walls of Smolensk (B). Later, documents in the same language from Jan Piotr Sapieha's field archives (C) were also included in the collection (Jan Piotr Sapieha died in Moscow in October 1611). The entire collection eventually ended up on the Sapieha family estate of Biaroza in present-day western Belarus (near Brest). Here, it was seized as war booty by the forces of Charles X (Karl X Gustav) of Sweden in the middle of the 17th century. In Sweden, the archives (D) were taken to Field Marshal Carl Gustaf Wrangel's castle of Skokloster, some $60 \mathrm{~km}$ north of Stockholm. The castle later passed by inheritance to the Brahe family, and the documents became part of what was known as the Brahe Collection (Tiumencev 2005: 32-33).

The Smolensk Archives $\left(\mathbf{F}_{2}\right)$ today consist of more than 500 archival units rolls of varying length comprising a total of some 1,500 sheets, currently stored in 23 boxes. $^{4}$

More than 360 archival units consist of a single sheet. The material is in striking disarray, with numerous fragments of originally longer rolls often to be found in

14 documents from the Smolensk Chancellery, which apparently have ended up here by mistake. Descriptions of these 14 documents will be included in the digital catalogue.

${ }^{4}$ In Russian archives, the pasted joins of rolls are often loosened, but this is not the practice at the Swedish National Archives, where rolls are stored in their original state. Very often, though, the joins have come unstuck by themselves. 
different archive boxes. It is not known when this disorder arose, but already in the 17th century the archives of course made at least two journeys through war-torn regions.

A good many of the rolls have brief descriptions of their contents in Polish on the verso, showing that the collection was examined and arranged in Poland. Far fewer documents have Russian inscriptions. These are written in black ink on the verso, and the handwriting is typical of the 19th century. This is probably Solov'ev's hand, indicating that the inscriptions originate from his visit to Sweden in the 1830 s, i.e. before the documents came to the National Archives. They sometimes consist of headings describing the contents of the longer rolls, but there are also brief comments on individual smaller fragments, e.g. "worthless fragments” (“негодные отрывки”, “дефекты”).

Virtually all the documents are numbered in pencil on the verso, most likely by the Russian historian Jurij Got'e, who worked on the collection around the turn of the last century. ${ }^{5}$ In 1898 he published a brief catalogue, in which he mentions that he has written numbers on the versos of the sheets (Got'e 1898: 16). In certain cases there is also numbering - clarifying Got'e's own - written in Ingvar Kalnins' hand. Kalnins was employed at the National Archives in Stockholm, where he worked with Russian documents from various collections during the last decades of the 20th century.

It appears that the rolls were previously stored in "bundles", a practice which, with the exception of the Smolensk Archives, is unknown in Swedish archives. In some boxes there are long strings with parchment labels attached, bearing inscriptions such as "The bundle (Вязка) IV". These inscriptions are written in a hand resembling Solov'ev's (cf. above). ${ }^{6}$

The condition of the paper in the collection varies. The longer rolls are all well preserved, while many of the single sheets have tears and holes in them and are damaged by damp, mould and ink corrosion. Some sheets have previously been conserved, using a variety of methods. Most commonly, thinned sheets have been pasted onto thicker brown paper. This was presumably done before 1910, as there are annotations in Got'e's hand on some of the brown sheets. Later, certain sheets were reinforced with Japanese paper. At present (2017), all the sheets are being conserved and placed in newly made boxes.

\footnotetext{
${ }^{5}$ The documents from Jan Piotr Sapieha's field archives, however, do not have pencil numbering. This supports the hypothesis that the numbering was added by Got'e, as he was only interested in documents connected with Smolensk.

${ }^{6}$ One indication that the labels were not written by a native speaker of Swedish is the fact that the word for "bundle" is in the definite ("knippan"), rather than the expected indefinite form ("knippa").
} 
The ink is a brownish colour, probably iron gall ink. In places it has faded to such a degree that the text is difficult to read.

The watermarks have yet to be analysed, but by far the commonest type consists of jugs of various kinds (several of these types are described in Dianova 1989, for example).

\subsection{The documents at the St Petersburg Institute of History (document collection $\boldsymbol{E}$ )}

The documents taken by Solov'ev to Russia in the 1830s are now in the archives of the St Petersburg Institute of History of the Russian Academy of Sciences, where they are held in two collections, koll. 124 and koll. 174. Brief descriptions of the contents can be found in three archival inventories: koll. 124, op. 1, and koll. 174, op. 1 and op. 2. These descriptions will be translated and included in the digital catalogue. A comprehensive review of how many sheets are now held in St Petersburg, and of how the Petersburg documents relate to the ones in Stockholm, has still to be completed, but what is quite clear is that a significant proportion of the Russian documents in the Brahe Collection were taken to St Petersburg in the 1830 s.

\section{Earlier descriptions of the collections}

Some of the documents which Solov'ev had taken to Russia were published in 1841 in the Archaeographical Commission's publication Akty istoričeskie (AI 1841). The policy of the Commission was to publish only dated documents from the Time of Troubles (Ivanov 1985: 93). The famous manuscript collector Pavel Stroev expressed the view that "the documents acquired in Sweden are highly interesting and must be read carefully and with concentration; through them, the history of the Time of Troubles emerges into the light from the earlier darkness and chaos"7 (Kovalenko 1988: 180).

In 1897 the young Russian historian Jurij Got'e visited the National Archives in Stockholm, where he came across the Smolensk Collection. In 1898 he published a brief catalogue, Smolenskie akty iz semejnago archiva gr. Brache. In the preface, Got'e writes that he was in fact looking for the "Brahehus Collection", which according to Solov'ev was kept at the National Archives and which was said to include 17 Russian

\footnotetext{
7 “...бумаги, приобретенные в Швеции, любопытны в высшей степени, их надобно читать прилежно и с большим вниманием; история Смутного времени выходит ими в свет из прежнего сумрака и хаоса."
} 
Löfstrand \& Ambrosiani (2017): "The Stockholm Smolensk Archives..."

CORRECTED PREPRINT. TO BE USED INSTEAD OF THE PUBLISHED VERSION

rolls (Got'e 1898: 3). ${ }^{8}$ Got'e discovered, however, that there were Russian rolls in the Brahe family archive, which had been deposited at the National Archives in 1893. He found these documents most interesting (Got'e 1898: 5). In 1840, in a report to the Archaeographical Commission, Solov'ev had written that the rolls at Skokloster Castle mainly comprised "defective fragments of criminal investigations", but Got'e took a different view, as he later pointed out in the preface to his text edition of 1912 (Got'e 1912: VI): "Having focused on the external deficiencies of the rolls [...], Solov'ev presumably did not notice that their contents chiefly relate to the administration of the Smolensk Chancellery during one of the most interesting and dramatic periods in the history of that city [...]." In preparation for the tercentenary of the Romanov dynasty in 1913, a decision was made in Russia to publish previously unknown documents related to the Time of Troubles, and to this end the National Archivist of Sweden, Emil Hildebrand, was asked in 1910 to send, with the permission of the Brahe family, all the rolls in the Smolensk Archives to the Rumjantsev Library in Moscow, where Jurij Got'e was able to work on them. ${ }^{10}$ The result was the text edition just mentioned, containing a great many documents from these archives (Got'e 1912). ${ }^{11}$ The material was arranged largely in chronological order of its creation, which meant, among other things, that longer rolls consisting of documents originating at different dates were not uncommonly divided into separate items, if other documents needed to be placed between the individual texts for reasons of chronology. Conversely, Got'e brought together documents found in different parts of the collection, but related in subject matter. $^{12}$

\footnotetext{
${ }^{8}$ These 17 rolls have never been found. There can be no question, though, of their being a subset of the rolls in the Smolensk Archives, as the latter did not arrive at the National Archives until long after Solov'ev's visit to Sweden.

9 “Обратив внимание на внешние дефекты столбцов [...], Соловьев не заметил, вероятно, что по содержанию своему они, главным образом, представляют делопроизводство Смоленской приказной избы в один из самых интересных и драматических моментов жизни этого города, [...]."

${ }^{10}$ That the documents were in fact sent to Moscow is all the more surprising, given that Got'e had not been given full access to the collection during his stay in Stockholm at the end of the 19th century, on the grounds that it was part of a family archive deposited in the National Archives (Got'e 1898: 15). All the documents were returned in February 1911 (Dmitrievsky, n.d.: 2).

${ }^{11}$ It is also clear that Got'e excluded a comparatively large number of documents from his edition of 1912, probably because of their fragmentary state. Unfortunately, it is still too early to say exactly how large a proportion of the documents in the Smolensk Archives are published in Got'e 1912.

${ }^{12}$ Got'e's text edition, sadly, is entirely devoid of references to his previously published catalogue (Got'e 1898), making it very difficult to link the published texts to the existing original documents.
} 
In recent years, Igor' Tiumencev and his research group have attempted to reconstruct Jan Piotr Sapieha's field archives (cf. Fig. 1, $\mathbf{C}_{\mathbf{0}}$ ), which are now scattered over many archival institutions in different countries. In connection with this, a large number of documents at IISPbRAN have been published, both previously unpublished material and reprints of material that appeared in AI 1841 (see Tiumencev 2012). The same edition also includes many documents from the Swedish National Archives, but not the 30 or so sheets that are part of the Smolensk Archives $\left(\mathbf{C}_{\mathbf{2 b}}\right)$. With one exception, ${ }^{13}$ there are no documents from Sapieha's field archives in Got'e 1912, either.

\section{Contents of the Stockholm Smolensk Archives}

As already mentioned, the Smolensk Archives at the National Archives in Stockholm $\left(\mathbf{F}_{2}\right)$ consist chiefly of documents from three separate 17th-century archives, which had become intermingled before that century was at an end: documents originating in the archives of the Chancellery of Smolensk during and after the siege of the city from 1609 to $1611^{14}\left(\mathbf{A}_{2}\right)$, documents from the camp of King Sigismund III of Poland outside Smolensk, from the same period $\left(\mathbf{B}_{2}\right)$, and documents from the field archives of Hetman Jan Piotr Sapieha $\left(\mathbf{C}_{\mathbf{2 b}}\right){ }^{15}$

\subsection{Documents from the Chancellery archives $\left(\boldsymbol{A}_{2}\right)$}

The documents from the Chancellery archives cover the period both before and during the siege. From the autumn of 1608 to the start of the siege in September 1609, the material relates almost exclusively to events in the countryside around Smolensk, above all in Poreckaja volost' and Ščučejskaja volost'. Only a few documents tell of events inside the city. One describes how three cowhides were stolen from a townsman. Others contain lists of individuals: people who have been released from prison on bail, and townsmen who are to defend the city, with details of the kinds of arms they bear.

Further, there are instructions from the Governors of Smolensk concerning guard duty in the towers.

The commonest type of document from before the siege consists of complaints from peasants in the villages about attacks and looting by the Polish-Lithuanian troops,

\footnotetext{
${ }^{13}$ See Got'e 1912, no. 281; this is also pointed out by Tiumencev (2005: 140).

${ }^{14}$ The siege began on 19 September 1609 and ended with the capture of the city on 3 June 1611.

${ }^{15}$ What is probably the oldest document in the collection, at least among those now preserved in the National Archives in Stockholm, is undated, but is said by Got'e (1912: 1, no. 1) to be from 1607. It is a report to Smolensk about the negotiations of the Tušino government and the second False Dmitrij with King Sigismund on preparations for an eastern campaign.
} 
accompanied by petitions for tax relief. They want the Governors, Michail Šein and Petr Gorčakov, to send strel'cy units to defend them. There is great unrest in the countryside. In the late spring of 1609 it is reported that many peasants have sworn an oath of allegiance to the Polish king, while others are standing by their oath to Tsar Vasilij Šjskij. This is causing internal strife within the peasant community. "Traitors" are attacking those loyal to the Tsar. Loyalist peasants in Poreckaja volost' complain that Ivan Lesunov and his family from Ščučejskaja volost' are conducting raids against them, and they want him taken to court. From this point on, the word "traitor" becomes part of the vocabulary of the Chancellery (Selin 2015: 19). There are also orders and reports relating to the building of roadblocks, with officials complaining of difficulties getting peasants to stand guard at them. Lists of noblemen who have failed to report for military duty, furthermore, show that the armed forces are not functioning effectively. In the complex political situation that has arisen, the nobility are putting their own interests first (Aleksandrov 2011: 150). People who have been in Polish captivity and can provide important information are questioned, for example about troop movements and estimates of numbers of soldiers. In late August 1609, the commander Ivan Židovin reports that the forces of the brothers Aleksander and Szymon Gosewski have taken the whole of Ščučejskaja volost', and that Poreckaja volost' is threatened with the same fate (Aleksandrov 2011: 154).

Documents of this kind are, by and large, no longer found after September 1609, when the city is besieged. During the siege, the Chancellery seems to have continued to operate broadly as before, though with certain limitations, as the city was now cut off from the surrounding countryside. ${ }^{16}$

The commonest types of material in 1610 are reports and investigations of disputes between townspeople (e.g. relating to theft, bodily injury and insults, and questions of inheritance). The Chancellery also received many reports from townspeople who had heard neighbours or acquaintances complaining about the siege, witnessed someone shirking their duties on the walls and in the towers, or heard someone agitating for the city to capitulate. Concern about being branded a "traitor" was justified.

During the siege, the Chancellery served as the headquarters for the defence of the city. The documents tell of how the defenders are armed, of the manning of towers

\footnotetext{
${ }^{16}$ This is probably the reason the documents preserved in the Smolensk Archives consist exclusively of rolls and fragments, and why no books (customs, land grant, or revenue and expenditure books) are preserved, as would otherwise have been expected.
} 
and walls, of efforts to conserve various food supplies (especially grain and salt), and of punishments meted out to individuals who have evaded military service or tried to escape from the city by lowering themselves on ropes from the walls. Severe penalties are imposed on those who fail. The number of attempted escapes increases as time goes by. There are many surety bonds - guarantees by a large number of named individuals that a certain person will not try to flee, but stay in the city and do his duty as a defender. Another type of document records the questioning of people who have managed to get into the city or who have been brought there in connection with breakouts from the fortress. Such people could be in possession of useful information about the besieging forces.

There are a great many lists of townspeople who have been allocated grain. Inside the city there were also many refugees from nearby towns and from the surrounding countryside. Their plight was particularly difficult, as they had generally not had time to bring any food with them from their homes. The authorities carefully record what stores of grain there are on the different properties in the city (Selin 2016a: 209). These long lists of names contain a great deal of information about the size and composition of households. And also about the women of the city - in general, women do not figure at all prominently in archives (see Selin 2016b). Several extensive lists relate to priests, monks and church servants and their households.

A rarer kind of document records orders from the Governors concerning measures to reduce the risk of fires. "Every day, in the morning, at noon, in the evening and at night", special watchmen are to ride around in the city and warn its inhabitants not to be careless with fire. Hoarding and speculating in food and brewing beer without permission are also strictly forbidden. These documents bring the difficult conditions in the city into sharp focus. ${ }^{17}$

\subsection{Documents from the Polish camp $\left(\boldsymbol{B}_{2}\right)$}

A small number of documents in the Smolensk Archives ${ }^{18}$ originate from Sigismund III's camp outside Smolensk. The Polish troops controlled the whole of the countryside around the city, and most of these documents consist of petitions applying for pay in the form of land or, more rarely, money. There are also two letters to the Chancellor, Lew

\footnotetext{
${ }^{17}$ Moločnikov (2015: 183) states that, alongside the documents from the Chancellery, the Brahe Collection also included "a small number of private letters" from Smolensk. Among the hitherto unpublished documents in the Stockholm Smolensk Archives, however, we have so far found only one such letter.

${ }^{18}$ See Got'e 1912, nos. 266-277.
} 
Sapieha, one from the d'jak Ivan Gramotkin and one from the boyar Michail Saltykov. ${ }^{19}$

\subsection{Documents from Jan Piotr Sapieha's field archives $\left(\boldsymbol{C}_{2 \boldsymbol{b}}\right)$}

The Smolensk Archives include just over 30 documents from the field archives of Jan Piotr Sapieha, each relating to a specific item of business. Only two of the documents consist of more than one sheet, and only six are dated (from 27 November 1608 to 29 March 1609). Twenty-five of the documents are petitions, addressed either to Jan Piotr Sapieha or to Tsar Dmitrij Ivanovič. The petitioners are often peasants, complaining of the ravaging and looting of the soldiers, or of the overwhelming levies imposed on them. Monasteries and churches have also been destroyed. Geographical names mentioned include districts such as Moskovskij uezd, Pereslavl-Zalesskij uezd, Rostovskij uezd and Vladimirskij uezd, Aleksandrova sloboda, and the towns of Jaroslavl' and Jur'ev-Pol'skij.

The documents from Sapieha's field archives also include a number of letters. One is from Fedor Kirillovič Pleščeev (Smerdov) to Vasilij Michajlovič Mosal'skijRubec and Prokofij Zachar'evič (family name unknown), both of them governors of the provincial town of Odoev, south-west of Tula (see Barsukov 1902: 159). Pleščeev was himself the governor of several Russian towns between 1607 and 1610 and he was close to Hetman Sapieha. During the first half of 1609 he was governor of Suzdal' (cf. Korsakova 1905: 115-117; Barsukov 1902: 219). In the letter to the two governors, Pleščeev takes them to task for a breach of etiquette: in correspondence to Sapieha, to the Polish knights and to Pleščeev himself, they had not referred to themselves with the humility that was customary when writing to superiors. ${ }^{20}$ Instead, they had written in a way that was reserved to the Tsar, thereby bringing shame on the whole Russian people: "You are after all Muscovites and not Poles." The letter ends on a more conciliatory note: "I am writing this to you out of love, so that you will not behave as badly in future." 21

The most spectacular letter in the field archives, however, has Ksenija Godunova - the daughter of Tsar Boris Godunov - as its sender. Jan Piotr Sapieha's forces besieged the Trinity-St Sergius Monastery from September 1608 until January

\footnotetext{
${ }^{19}$ See Got'e 1912, nos. 278 and 279. Got'e has placed both these letters under the heading "Documents from the Polish camp" (“Документы из польского стана"), even though, according to Got'e himself, they have no connection with Smolensk; cf. Got'e 1912: XVI. 20 "Писали есте $[. .$.$] себя с вичом..."$

${ }^{21}$ For this so far unpublished letter, see RA, Skoklostersamlingen, Handlingar från Smolensk, E 8610: 04b, PEA 52.
} 
Löfstrand \& Ambrosiani (2017): "The Stockholm Smolensk Archives..."

CORRECTED PREPRINT. TO BE USED INSTEAD OF THE PUBLISHED VERSION

1610 , and among those confined within its walls was the Tsar's daughter and nun Ksenija (Olga). On 1 April 1609 three strel'cy who were heading for Moscow were captured. They were carrying some 500 letters (Tiumencev 1995: 26). Among them, there were two from Ksenija Godunova to her relatives in Moscow. One of these is preserved in the Solov'ev Collection in St Petersburg, and is addressed to Domna Bogdanovna Nogotkova, who is referred to as her "aunt". The letter in the Swedish National Archives, on the other hand, is addressed to her "grandmother" Stefanida Ondreevna. The three women were not in fact as closely related as this, as Adrian Selin has pointed out in an article (Selin 2016a: 71-76). The hope was no doubt that some kind of assistance would be forthcoming from Moscow. Ksenija Godunova's two letters were written on the same date $(29$ March) and in the same hand. They are very similar in content, and include many similar wordings. "[We are] scarcely alive from our privations. The nuns and I are seriously ill. We cannot hope to survive here. For our sins, and owing to perfidy and treason, the plague has struck us here under the siege. Great mortal sorrow afflicts many people, and every day twenty or thirty dead are buried, sometimes more." 22

Ksenija Godunova's letter in the Solov'ev Collection is well known to scholars. It was printed as early as 1841 in Akty istoričeskie (see AI 1841: 213, no. 182a), ${ }^{23}$ together with another intercepted letter, sent by Ksenija's servant Solomonida Rževskaja, but written on a different occasion.

The letter held in the Swedish National Archives, on the other hand, was unknown to scholarship until January 2015: Got'e makes no mention of it, even though he may reasonably be assumed to have known of it. But, as already noted, he confines his attention strictly to the documents from Smolensk. Photographic reproductions of both letters can be found in Selin 2016a: $74-75^{24}$

\footnotetext{
${ }^{22}$ See RA, Skoklostersamlingen, Handlingar från Smolensk, E 8610: 04a, PEA 34. A third letter, from the monastery servant Grigorij Rjazanov to his son-in-law Petr Tugrinov, is reproduced by Tiumencev (1995: 38, 2012: 229 - the original is kept in RA, Skoklostersamlingen, E 8610 (no. 344, Ryska brev)). This letter, too, is dated 29 March 1609, and the wording is strikingly similar to those of the two from Ksenija Godunova. In some places the three letters match word for word, for example when it comes to specific information about life in the besieged monastery. As all three are also in the same hand, they were probably written at the same time.

${ }^{23}$ Extracts from Ksenija Godunova's letter to Domna Bogdanovna Nogotkova have now also been published on Russian Wikipedia; see https://ru.wikipedia.org/wiki/Годунова, Ксения_ Борисовна (accessed 3 January 2016).

${ }^{24}$ Unfortunately, however, the illustrations have been confused: the letter shown on p. 74 is in fact the one to Domna Nogotkova, while the letter to Stefanida Ondreevna is on p. 75.
} 


\subsection{Other documents in the Smolensk Archives}

The Smolensk Archives also include nine short documents, mainly lists of various kinds, which differ from the other material in terms of the size of the paper (narrow strips, 8-15 cm wide), the colour of the ink (brownish black to black), and the handwriting (skoropis' of a south-west Russian type). In Got'e's catalogue they are included in bundle no. 38 (Got'e 1898: 26): "Bundle (roll) 38 [...]: 2 Polish documents and 7 western Russian. The latter include accounting records [...]; there are also fragments of lists of names. [...] The hand and the orthography differ markedly from those of the Muscovite rolls., 25

These nine documents are definitely not part of the Chancellery archives, nor do they resemble the material originating from Jan Piotr Sapieha's field archives or the camp of Sigismund III. They may possibly have a connection with the documents from Prince Semen Bel'skij's archive from the 1540s (see Dmitrievsky, n.d.: 2), which are also part of the National Archives' Skokloster Collection. ${ }^{26}$

\section{Conclusion}

As we have attempted to show, the documents now held in the "Smolensk Archives" at the Swedish National Archives in Stockholm form part of a complex web of document collections and archives that originated in early 17th-century Russia and Poland, were subsequently mixed together and divided up, and are today preserved in archival institutions in both Russia and Sweden. Some of the documents were published as early as the mid 19th century and the beginning of the 20th, but an overall survey of all the material preserved, including a description of what has been published to date and what remains to be published, has yet to be made. It is our hope that, with the Digital Catalogue of the Stockholm Smolensk Archives project, we will be able to move some steps closer to that goal.

\section{Works cited}

\section{AI 1841 = Акты исторические, собранные и изданные Археографической коммиссиею. Том второй, 1598-1613, 1841, Санкт-Петербург.}

\footnotetext{
25 “Вязка (столбеи) No. 38 [...]: 2 польских и 7 западно-русских. Содержание последних хозяйственное [...]; есть также отрывки каких-то именных списков. [...] Почерк и орфография значительно отличаются от почерка и орфографии Московских столбцов.” These documents are not published in Got'e 1912.

${ }^{26}$ See boxes RA, Skoklostersamlingen, E 8610: 2 and E 8610 (no. 344, Ryska brev). The first of these boxes also contains Jan Piotr Sapieha's diary in the original (cf. Tiumencev 2005: 16).
} 
Aleksandrov 2011 = Александров, С. В., 2011, Смоленская осада 1609-1611, Москва: Вече.

Barsukov 1902 = Барсуков, А. П., 1902, Списки городовых воевод и других лич воеводского управления Московского государства XVII столетия, СанктПетербург: Тип. М. М. Стасюлевича.

Dianova 1989 = Дианова Т. В., 1989, Филигрань кувиин XVII века, Москва.

Dmitrievsky, S. (n.d.), Utkast till PM över ryska handlingar bland

Skoklostersamlingens polska handlingar. [Typescript, partly manuscript.]

(Swedish National Archives, Reading Room Order Desk.)

Dmitrievsky, S., 1959, P.M. rör. Skoklosterarkivets polska handlingar. [Typescript.] (Swedish National Archives, Reading Room Order Desk.)

Got'e 1898 = Готье, Ю. В., 1898, Смоленские акты из семейного архива гр. Брахе, Москва: Снегирева.

Got'e 1912 = Готье, Ю. В., 1912, Памятники обороны Смоленска 1609-1611 г2. (= Смутное время Московскаго государства 1604-1613 гг. Материалы, изданные Императорским обществом Истории и Древностей Российских при Московском Университете, вып. 6-ой), Москва: Синодальная типография.

Ivanov 1985 = Иванов, Ю. А., 1985, “Документы русских архивов начала XVII века в коллекции С. В. Соловьева”, Археографический ежегодник за 1983 г., Москва, 91-95.

Korsakova 1905 = Корсакова, В., 1905, “Плещеев, Феодор Кириллович”, Русский биографический словарь: Правильщиков - Примо, Санкт-Петербург, 115117.

Kovalenko 1988 = Коваленко, Г. М., 1988, “Архивные изыскания С. В. Соловьева в Швеции", Скандинавский сборник XXXII, 179-183.

Löfstrand, E., \& Nordqvist, L., 2005, Accounts from an Occupied City: Catalogue of the Novgorod Occupation Archives 1611-1617. Series I. Skrifter utgivna av Riksarkivet 24. Stockholm: Riksarkivet.

Löfstrand, E., \& Nordqvist, L., 2009, Accounts from an Occupied City: Catalogue of the Novgorod Occupation Archives 1611-1617. Series II. Skrifter utgivna av Riksarkivet 31. Stockholm: Riksarkivet.

Moločnikov 2015 = Молочников, А.М., 2015, “Военная и политическая организация смоленской городской общины в 1609-1611 гг”, История 
Löfstrand \& Ambrosiani (2017): "The Stockholm Smolensk Archives..." CORRECTED PREPRINT. TO BE USED INSTEAD OF THE PUBLISHED VERSION

военнога дела: исследования и источники, спецу. вып. IV. Смоленские войны $X V-X V I I$ вв., ч. I, 182-203

Selin

[http://www.milhist.info/2015/12/17/molochnikov_5]

, A., 2015, "Lithuanian Borderline in 1609, view from the Smolensk Chancellery", Białoruskie Zeszyty Historyczne, vol. 44, 19-27.

Selin, A., 2016a, "The archives of the two Sapiehas and the two letters by Xenia Godunova", Пяты Міжнародны Кангрэс даследчьлкай Беларусі, Працоўныя матэрыялыь [Pjaty mižnarodny kangrès dasledčykau Belarusi, Pracounyja materyaly], vol. 5, Kaunas: Vytautas Magnus University Press, 71-76.

Selin 2016b = Селин, А. А., 2016, “Женщины в осажденном Смоленске”, $D a$ veselitsja Nov"grad" = Må Novgorod fröjda sig: hyllningsskrift till Elisabeth Löfstrand, ed. Per Ambrosiani, Per-Arne Bodin \& Nadezjda Zorikhina Nilsson, Stockholm: Stockholm University, 207-219.

Spisok 2013 = Список фондов по Русской секции Научно-исторического Архива СПбИИ РАН. [http://www.spbiiran.nw.ru/wpcontent/uploads/2013/10/Список_фондов_по_Русской_секции_.pdf]

Tiumencev 1995 = Тюменцев, И. О., 1995, Очерки по истории оборонь ТроицеСергиевой лавры, Волгоград: Изд-во Волгоградского государственного университета.

Tiumencev et al. 2005 = Тюменцев, И. О., Мирский С. В, Рыбалко Н. В., Тупикова, Н. А., Тюменцева Н. Е., 2005, Русский архив Яна Сапеги 1608-1611 годов: опыт реконструкции и источниковедческого анализа, Волгоград: Изд-во Волгоградского государственного университета.

Tiumencev et al. 2012 = Тюменцев, И. О., Тупикова Н. А., Тюменцева Н. Е., Мирский С. В, 2012, Русский архив Яна Сапеги 1608-1611 годов: тексты,, nереводы, комментарии, Волгоград: Изд-во Волгоградского филиала ФГБОУ ВПО РАНХиГС. 